JEL: L20, M10

DOI: 10.5937/industrija42-5905

UDC: 005.6:640.4

Original Scientific Paper

\title{
Total Quality Management as a Profitability Factor in the Hotel Industry
}

\author{
Article history: \\ Received: 11 April 2014 \\ Sent for revision: 26 May 2014 \\ Received in revised form: 5 July 2014 \\ Accepted: 23 July 2014 \\ Available online: 1 November 2014
}

\begin{abstract}
This paper focuses on assessing the impact of TQM implementation on the financial performance of hotels. According to the previous studies from Spain, Singapore, Malaysia, and the USA, an empirical investigation was conducted in Serbia during the first quarter of 2013. The findings revealed that the hotels practiced TQM at a relatively high level, especially customer orientation and teamwork. However, the analysis did not yield clear evidence that a higher level of TQM implementation impacted positively on the financial performances of hotels. The present research complements the existing literature on total quality management, and is the first attempt in Serbia to measure the financial consequences of TQM implementation. It aimed to raise the awareness among hoteliers regarding the importance of quality, and to support further analysis on the effects of $T Q M$, especially in developing countries, which generally lack research of this kind, particularly in the hotel industry.
\end{abstract}

Keywords: Total quality management, hotel industry, financial performance, profitability

\section{Menadžment ukupnog kvaliteta kao faktor profitabilnosti u hotelskoj industriji}

Apstrakt: Rad nastoji da identifikuje uticaj implementacije menadžmenta ukupnog kvaliteta na finansijske performanse hotelskih preduzeća. Na osnovu ranijih istraživanja u Španiji, Singapuru, Maleziji i SAD-u, sprovedeno je empirijsko istraživanje u Srbiji tokom prvog kvartala 2013. godine. Rezultati

\footnotetext{
${ }^{1}$ University of Kragujevac, Faculty of Hotel Management and Tourism in Vrnjačka Banja, vesna.milovanovic@kg.ac.rs
} 
Milovanović V.: Total Quality Management as a Profitability Factor in the Hotel...

pokazuju da je nivo implementacije menadžmenta ukupnog kvaliteta u našim hotelima relativno visok, posebno kada se radi o ključnim faktorima kao što su orijentacija na kupce i timski rad. Ipak, analiza nije podržala hipoteze da viši nivo implementacije menadžmenta ukupnog kvaliteta pozitivno utiče na finansijske performanse hotela. Rad dopunjuje postojeću literaturu na temu menadžmenta ukupnog kvaliteta, a istovremeno predstavlja i prvi pokušaj u Srbiji da se izmere finansijske posledice implementacije ove sofisticirane filozofije. Takođe nastoji da podstakne širenje svesti o značaju kvaliteta među hotelijerima, kao i dalje analize efekata menadžmenta ukupnog kvaliteta, posebno u zemljama u razvoju, u kojima su istraživanja ove vrste još uvek oskudna, naročito kada je reč o hotelskoj industriji.

Ključne reči: Menadžment ukupnog kvaliteta, hotelska industrija, finansijske performanse, profitabilnost,

\section{Introduction}

Total quality management (TQM) is a management philosophy that focuses on continuous process improvement aiming to ensure superior productivity and profitability (Wang et al., 2012). TQM refers not only to the management of quality but also to the quality of management (Brah \& Wong, 2000). According to this holistic philosophy companies undertake risk, make mistakes and most importantly - they learn from mistakes and develop skills as a basis for competitive advantage. In such a way companies build a unique identity which is impossible to be copied. It involves a set of practices addressed to the satisfaction of customers' expectations, reduction of repairs, employee involvement and teamwork, process redesign, comparative analysis, continuous measurement of results and stronger supplier relationships. A fundamental assumption of TQM is that the cost of low quality is greater than the cost of developing processes that ensures high quality. Quality is therefore seen as the basis for competitive strategy development.

Implementation of TQM is rather complicated because it requires a commitment of all individuals in an organization. Companies must realize that TQM philosophy does not refer only to the adoption of its principles, but also requires the existence of complementary factors such as: a culture susceptible to changes, motivation for promotion, people capable of understanding and applying specific TQM practices, people who possess corporate persistence and leadership qualities, and perhaps a certain external factor that induces change and learning (Janošević \& Dženopoljac, 2013). Oakland (2011) points out that sustainable profitability requires soundly based, systematic, and continuously improved processes, and effective deployment of TQM strategies and policies. Today, TQM stands for a broad 
Milovanović V.: Total Quality Management as a Profitability Factor in the Hotel...

concept which includes economic, social and environmental concern, especially in the hotel industry (Jones et al., 2014). To emphasize the importance of quality, there are prestigious awards for business excellence: Deming Prize in Japan, Malcolm Baldrige National Quality Award in the USA, and European Quality Award in Europe.

The present work is organized as follows. After literature review regarding TQM impact on business performances, and requirements for successful TQM implementation, the research model will be presented. The research results are followed with discussion and conclusions.

\section{Literature review}

The TQM concept has been the subject of numerous studies, though results are not consistent when it comes to the impact of TQM on a company's performances. This may be due to different research approaches - whether the accent was on operative, financial or market performances; whether only direct impacts of TQM were considered or also indirect impacts; and different technical methods of measurement. There are no many studies about the impact of TQM on hotels' financial performance. That is why the literature consulted all the research conducted to test the relationship between TQM and companies' performances.

Brah et al. (2000) have shown the positive impact of TQM on business performances in the Singapore service sector, identifying top management commitment and employee involvement as key success factors. However, they found that TQM impacts Research from Spain by Escrig-Tena (2004) demonstrated a positive impact of TQM on quality, operative and financial results. Benavides-Velasco et al. (2014) showed a positive impact of TQM implementation on hotels performance in Spain. Claver-Cortes et al. 2008 found that TQM positively impacts on competitiveness but there was no correlation between TQM and financial performance. A study from Malaysia (Agus \& Sagir, 2001) discovered an indirect impact of TQM on financial results - TQM directly affected competitive advantage, which in turn improved financial results. Kaynak (2003) conducted research in the USA and also showed a positive impact of TQM on a company's financial results. He saw a lack of top management commitment as a possible cause of ineffective TQM implementation. Douglas and Judge (2001) have established a strong relationship between the level of TQM implementation and competitive advantage of companies in the USA, and assessed the impact of organizational culture on TQM effectiveness.

Implementing TQM requires major changes of management tools, organizational structure, attitudes and behavior of all members sharing the 
Milovanović V.: Total Quality Management as a Profitability Factor in the Hotel...

same value system. Processes are the means for companies to release the potential of employees to achieve results, so processes and people are agents that produce results. TQM implementation in the service sector encounters the following problems:

- due to their nature service industries have less control over factors affecting quality;

- as services cannot be stored for later use and because of the customer's involvement in service production, there is a higher level of external risk comparing with other industries;

- service intangibility poses a barrier in the creation of standards, and their implementation and measurement;

- a good service is based on the customer's expectations which may be unknown or unsaid and may vary from customer to customer as well as over time;

- $\quad$ service quality is difficult to be measured due to its subjective nature.

TQM is not only about achieving a certain level of quality but also about continuous improvement of all processes and activities in a company, since the competitive advantage to be achieved is indeed a "moving target" (Đuričin et al., 2010). Improvement requires information collection, system analysis and feedback, as well as systematic procedures for planning, realization and evaluation. To achieve this, it is necessary to standardize processes, use various improvement tools, collect performance indicators, and conduct benchmarking and self-evaluation (Escrig-Tena, 2004). TQM requires reforms in key organizational features, especially in management style and culture, as well as complete restructuring of social relationships inside a company and between a company and its stakeholders. TQM promotes training, employee involvement, teamwork and opening communication channels to collect information and knowledge.

The literature has identified common practices leading to successful TQM implementation, such as leadership, quality planning, employee management, customer orientation, process management, supplier management, information and analysis, care for the community and natural environment (Saraph et al., 1989; Flynn et al., 1994; Ahire et al., 1996). Training, ICT, and care for the environment are especially important for hotel industry (Brotherton, 2004). Employees need training to identify and solve problems, improve working methods, and take the responsibility for quality. Training adds strategic value to hotel companies because service quality depends on the effectiveness of employees in satisfying the customer needs. Hotels having a higher level of TQM implementation ensure a wide array of training options for employees (Tsaur \& Lin, 2004). Similarly, ICT/IS plays an important role in quality improvement and customer satisfaction. Companies see the rising impact of ICT on TQM dimensions, so those two are in a 
Milovanović V.: Total Quality Management as a Profitability Factor in the Hotel...

positive correlation (Martinez-Lorente et al., 2004). ICT increases productiveness by reducing time and costs for conducting routine operations and enabling automation of such operations. In this way, employees have more time to care about guests. There are new services arising from ICT/IS: the Internet, Wi-Fi, cable TV - which increase the level of customer satisfaction in hotels. Companies having higher levels of TQM implementation implement more ICT/IS (Claver-Cortés et al., 2008). Mosadeghrad (2014) emphasized that the most frequently mentioned reasons for TQM implementation failures are: insufficient education and training, lack of employees' involvement, lack of top management support, lack of a qualityoriented culture, poor communication, lack of a plan for change and employee resistance to the change programme. Vora (2013) argues that business excellence demands sustainable change where leadership, project and talent management play an important role. Similarly, Antony (2013) states that quality managers need to adapt quality-based management programmes to fit the new business era instead of continuing with systems that may have worked in the past. Findings of Green (2012) suggest that successful implementation of TQM could depend on the prevailing culture of the company. Furthermore, Park et al. (2012) showed that managing individual fatigue and stress decreases the number of individual errors.

The hotel industry cares about service quality because of its impact on internal performances (productivity, costs and waste), and external performances (sales and market share, customer satisfaction, corporate image). As far as we are aware, no previous studies have been carried out on the impact of TQM on the hotel industry in Serbia.

\section{Research methodology}

TQM can be regarded as a strategic option that includes integration of different principles and practices. However, companies do not place the same weight on all the principles. TQM is therefore a continuum where companies are located according to their commitment to each of the TQM principles. A set of critical factors determining the level of TQM implementation was determined according to previous studies in this field (Saraph et al., 1989; Flynn et al., 1994; Powell, 1995; Ahire et al., 1996; Black \& Porter, 1996; Hanson \& Eriksson, 2002; Kaynak, 2003; Claver-Cortés et al., 2008):

- Top management commitment

- Customer orientation

- Supplier relationship

- Employee involvement

- Teamwork 
Milovanović V.: Total Quality Management as a Profitability Factor in the Hotel...

- Training

- Error prevention

- $\quad$ IT and statistical methods for process improvement

- Benchmarking

- Quality data

- Rewards for quality improvements

The primary goal of each company is to create economic value for its owners. It is therefore important to measure the contribution of TQM to profit creation. By testing whether a relationship exists between the level of implementing TQM and profitability indicators.

- H1: There is a significant positive relationship between level TQM implementation and the rate of return on investment (ROE).

- $\quad$ H2: There is a significant positive relationship between level of TQM implementation and the rate of return on assets (ROA).

Empirical data were collected by a questionnaire containing 46 questions, around 4 per critical factor identified above. The questionnaire was sent to general managers of 43 independent hotel companies categorized as 3 to 5 stars by the Ministry of finance and economy of the Republic of Serbia. The categorization list was from 31.12.2012. Thirtyfour hotels, 79\% of those approached, participated in the research. The five-point Likert scale was used to score managers' agreement with the provided statements (1=strongly disagree, 2=disagree, 3=neutral, 4=agree, 5=strongly agree). Managers were also asked to answer with "yes" or "no" to the question if their hotel has implemented ISO 9001 quality management standards. Profitability indicators were:

- $\quad$ rate of return on equity (ROE), as a ratio of net gain and owners' equity

- $\quad$ rate of return on assets (ROA), as a ratio of net gain and total assets

Data used for counting profitability indicators were taken from the hotels' financial reports from 2012, published by the Agency for business registers of the Republic of Serbia. The Cronbach's Alpha coefficient was used to test the internal consistency of measuring scale for the level of TQM implementation. The coefficient value (0.98) indicates good internal consistency of the measuring scale. The strength of relationships between the level of TQM implementation and profitability indicators was tested by the Spearman's correlation coefficient. All statistical tests were evaluated at the 0,05 alpha reliability level. Statistical analysis was conducted using statistical software SPSS 13.0 (SPSS Inc, Chicago Illinois, USA). 
Milovanović V.: Total Quality Management as a Profitability Factor in the Hotel...

\section{Results and discussion}

Descriptive statistics for variable TQM can be observed from Table 1. The mean is closer to the edge with maximum value, indicating that the level of TQM implementation is rather high in the Serbian hotel industry. Another indicator of the TQM implementation level could be the number of certificates for ISO 9001 quality management standards, since this set of standards is often regarded as materialization of TQM philosophy. In Serbia, $76.5 \%$ of examined hotels have certified ISO9001 quality management system, what indicates that significant effort was made by hotels to improve their quality management system.

Table 1. Descriptive statistics for the variable TQM.

\begin{tabular}{ccccc}
\hline N & Min & Max & Mean & Std. \\
Statistic & Statistic & Statistic & Statistic & Statistic \\
34 & 73.00 & 225.00 & 186.2325 & 30.14215 \\
\hline \multirow{3}{*}{ Skewness } & Kurtosis & & \\
& Statistic & Std. Error & Statistic & Std. Error \\
& -1.880 & 0.4 & 5.306 & 0.79 \\
\hline
\end{tabular}

Source: Author's calculations

Normality of the variables' distribution was tested using the Shapiro-Wilk's test (see Table 2).

As the assumption about normality was not fulfilled, nonparametric statistical tests were used for further analysis.

Table 2. The Shapiro-Wilk's test.

\begin{tabular}{lccc}
\hline & Statistic & df & Sig. \\
TQM & 0.852 & 34 & 0.000 \\
ROE & 0.249 & 34 & 0.000 \\
ROA & 0.616 & 34 & 0.000 \\
\hline
\end{tabular}

Source: Author's calculations 
Milovanović V.: Total Quality Management as a Profitability Factor in the Hotel...

Mean values and standard deviation of each TQM factor can be observed in Table 3. The hotels practiced teamwork and customer orientation at a very high level, while they poorly used IT and statistical techniques for process improvement, as well as training and rewards. This could be explained by the fact that the last three factors require some sort of investment, but many hotels are reluctant to make additional costs in the short-run, especially during the economic crisis. Also, there can be an impact of rather low technological readiness of the Serbian market (World Economic Forum - Global Competitiveness Report 2012).

Table 3. Descriptive statistics of the TQM key factors.

\begin{tabular}{lc}
\hline TQM key factors & Mean \\
Top management commitment & 4.3647 \\
Customer orientation & 4.5294 \\
Supplier relations & 4.3059 \\
Employee involvement & 4.2647 \\
Teamwork & 4.5588 \\
Training & 3.7745 \\
Error prevention & 4.1275 \\
IT and statistical methods for process improvement & 3.0294 \\
Benchmarking & 4.3431 \\
Quality data & 4.0956 \\
Rewards for quality improvement & 3.5000 \\
\hline
\end{tabular}

Source: Author's calculations

The correlation analysis was conducted inside the group of TQM factors at the significance levels $\alpha=0.01$ and $\alpha=0.05$. The highest correlation was obtained between the factors Quality data and Error prevention (0.822). Factors that positively correlated with all the other factors are Top management commitment, Employee involvement, Training, Error prevention, Quality data, and Rewards for quality improvement. It means that improvement of any of these factors will have a multiplicative effect on the overall level of TQM.

Table 4 presents the results of correlation analysis between the level of TQM implementation and ROE. The Spearman's correlation coefficient is -0.041 . This is a very weak relationship between the two variables, meaning that higher level of TQM implementation does not imply an increase in ROE. Therefore we reject the hypothesis $\mathrm{H} 1$. 
Milovanović V.: Total Quality Management as a Profitability Factor in the Hotel...

Table 4. The Spearman's correlation coefficient.

\begin{tabular}{|c|c|c|c|c|}
\hline & & & TQM & ROE \\
\hline \multirow[t]{6}{*}{$\begin{array}{l}\text { Spearma } \\
\text { n's rho }\end{array}$} & TQM & $\begin{array}{l}\text { Correlation } \\
\text { Coefficient }\end{array}$ & 1.000 & -0.041 \\
\hline & & Sig. (2-tailed) & . & 0.819 \\
\hline & & $\mathrm{N}$ & 34 & 34 \\
\hline & ROE & $\begin{array}{l}\text { Correlation } \\
\text { Coefficient }\end{array}$ & -0.041 & 1.000 \\
\hline & & Sig. (2-tailed) & 0.819 & . \\
\hline & & $\mathrm{N}$ & 34 & 34 \\
\hline
\end{tabular}

Source: Author's calculations

The results of correlation analysis between the level of TQM implementation and ROA are presented in Table 5. The Spearman's correlation coefficient of 0.03 indicates a very weak relationship between the two variables, indicating that the higher level of TQM implementation does not cause an increase in ROE. The hypothesis $\mathrm{H} 2$ is being rejected.

Table 5. The Spearman's correlation coefficient.

\begin{tabular}{|c|c|c|c|c|}
\hline & & & TQM & ROA \\
\hline \multirow[t]{6}{*}{$\begin{array}{l}\text { Spearman' } \\
\text { s rho }\end{array}$} & TQM & $\begin{array}{l}\text { Correlation } \\
\text { Coefficient }\end{array}$ & 1.000 & 0.003 \\
\hline & & Sig. (2-tailed) & . & 0.987 \\
\hline & & $\mathrm{N}$ & 34 & 34 \\
\hline & ROA & $\begin{array}{l}\text { Correlation } \\
\text { Coefficient }\end{array}$ & 0.003 & 1.000 \\
\hline & & Sig. (2-tailed) & 0.987 & . \\
\hline & & $\mathrm{N}$ & 34 & 34 \\
\hline
\end{tabular}

Source: Author's calculations

By rejecting both hypotheses we conclude that there is no relationship between the level of TQM implementation and hotels' financial performances in Serbia. However, these results could be affected by several possible reasons. Firstly, the research has identified an overall weak investment in quality through training and rewards. As several studies have emphasized (Allen \& Kilmann, 2001; Yeh, 2003; Jun, Cai \& Peterson, 2004) these factors are of special importance in motivating employees to implement TQM practices more effectively. Thus, insufficient attention paid to rewarding and 
Milovanović V.: Total Quality Management as a Profitability Factor in the Hotel...

training may be the cause of ineffective TQM implementation and thus a poor improvement of financial performance, although some other factors were practices very well. Secondly, there might be some organizational barriers preventing successful implementation of TQM values, such as corporate structure and national as well as organizational culture. Thirdly, it could be that many Serbian hoteliers are still not familiar with contemporary quality management philosophy, what might have affected their ability to provide a realistic appraisal of our statements. Furthermore, TQM is known to produce benefits in the long-run, thus observing the relationship between TQM and financial indicators at a single moment may produce misleading results. At the end, exogenous nuisances might have significantly violated the relationship between TQM practices and financial performances of hotels.

The results of the present study are consistent with those of Claver-Cortes et al. (2008) who found that TQM may have a positive influence on competitive performance and stakeholder satisfaction, but no influence on financial performance of Spanish hotels. Other studies that have confirmed positive impact of TQM on financial performances (Kaynak, H., 2002; Brah, S. et al., 2000; Hansson, J. \& Eriksson H., 2002, Escrig-Tena, A., 2004, Agus \& Sagir, 2001) have not analyzed the hotel companies only, but the whole business sector. There can not be found many studies on the impact of TQM on hotels' financial performance. It could be that TQM does not produce an advantage for hotels in financial terms, although it may be different with other types of companies. However, further research is needed to clarify this assumption.

\section{Conclusions}

Although the concept of TQM has emerged after the Second World War, the effects of its implementation on business performances are unclear even today. Many studies worldwide attempted to estimate the relationship between the above mentioned variables, but results are still inconsistent. Difficulties related to measuring the level of TQM implementation influence also the final result, that is, the relationship between TQM and financial performances.

The present study was a pioneer attempt in Serbia to establish a relationship between the level of TQM implementation and financial performances of hotels. The assessment of TQM implementation in Serbian hotels showed that there exists a relatively high level of concern about quality. The most practiced TQM factors are customer orientation, teamwork and top management commitment, while there is a low level of investment in training and rewards for quality improvement. The research however did not yield clear evidence that there exists a relationship between the level of TQM 
Milovanović V.: Total Quality Management as a Profitability Factor in the Hotel...

implementation and hotels' financial performances. This is most probably the consequence of a relatively small sample. Also, there is evidence that some TQM principles were not exercised correctly, as hotels showed low concern for training and motivation of employees. Without training employees can not develop competences necessary for continuous quality improvement and without rewards they will not be motivated to contribute. It can be concluded that the core of TQM philosophy is not properly understood among hotel managers in Serbia who at the same time claim commitment to this philosophy. Intensified research may help hotel managers understand the importance of TQM for achieving and sustaining competitive advantage, and also show the right way for TQM successful implementation.

Further analyses are welcome to complement the scarce literature on the effects of TQM on hotels' financial performances. It would be beneficial to estimate the impact of TQM on non financial performances as well, such as customer and employee satisfaction and retention, market share, efficiency of processes, and to include long-term performances in the analysis.

\section{References}

Ahire, S.L., Golhar, D.Y., \& Waller, M.A. (1996). Development and Validation of TQM Implementation Constructs. Decision Sciences, 27(1), 23-56. doi:10.1111/j.1540-5915.1996.tb00842.x

Allen, R.S., \& Kilmann, R.H. (2001). The role of the reward system for a total quality management based strategy. Journal of Organizational Change Management, 14(2), 110-131. doi:10.1108/09534810110388036

Antony, J. (2013). What does the future hold for quality professionals in organisations of the twenty-first century? The TQM Journal, 25(6), 677-685. doi:10.1108/TQM07-2013-0079

Benavides-Velasco, C.A. (2014). Total quality management, corporate social responsibilityand performance in the hotel industry. International Journal of Hospitality Management, 41, 77-87. doi:10.1016/j.ijhm.2014.05.003

Black, S.A., \& Porter, L.J. (1996). Identification of the Critical Factors of TQM. Decision Sciences, 27(1), 1-21. doi:10.1111/j.1540-5915.1996.tb00841.x

Brah, S., Wong, J., \& Rao, B. (2000). TQM and business performance in the service sector: A Singapure study.International Journal of Operations \& Production Management, 20(11), 1293-1312.

Brotherton, B. (2004). Critical success factors in UK budget hotel operations. International Journal of Operations AND Production Management, 24(9), 944-969.

Claver-Cortés, E., Pereira-Moliner, J., Tari, J.J., \& Molina-Azorin, J.F. (2008). TQM, managerial factors and performance in the Spanish hotel industry. Industrial Management and Data Systems, 108(2), 228-244. doi:10.1108/02635570810847590 
Milovanović V.: Total Quality Management as a Profitability Factor in the Hotel...

Deming, W.E. (1982). Quality, Productivity and Competitive Position. Cambridge: MIT Center for Advanced Engineering.

Đuričin, N., Janošević, S., \& Kaličanin, M. (2010). Menadžment i strategija. Beograd: Ekonomski fakultet.

Escrig-Tena, A.B. (2004). TQM as a competitive factor. International Journal of Quality \& Reliability Management, 21(6), 612-637. doi:10.1108/02656710410542034

Flynn, B., Schroeder, R., \& Sakakibara, S. (1994). A framework for quality management research and an associated measurement instrument. Journal of Operations Management, 11(4), 339-366. doi:10.1016/S0272-6963(97)90004-8

Green, T.J. (2012). TQM and organisational culture: How do they link?. Total Quality Management and Business Excellence, 23, 141-157. doi:10.1080/14783363.2012.647847

Hansson, J., \& Eriksson, H. (2002). The impact of TQM on financial performance. Measuring Business Excellence, 6(4), 44-54. doi:10.1108/13683040210451714

Janošević, S., \& Dženopoljac, V. (2013). The balanced scorecard vs. Total quality management. TTEM, 8(1), 373-383.

Jones, P., Hillier, D., \& Comfort, D. (2014). International Journal of Cotemporary Hospitality Management, 26(1), 5-17. doi:10.1108/IJCHM-10-2012-0180

Jun, M., Cai, S., \& Peterson, R.T. (2004). Obstacles to TQM Implementation in Mexico's Maquiladora Industry. Total Quality Management \& Business Excellence, 15(1), 59-72.

Kaynak, H. (2003). The relationship between total quality management practices and their effects on firm performance.Journal of Operations Management, 21(4), 405-435. doi:10.1016/S0272-6963(03)00004-4

Martinez-Lorente, A.R., Sanchez-Rodriguez, C., \& Dewhurst, F.W. (2004). The effect of information technologies on TQM: an initial analysis. International Journal of Production Economics, 89(1), 77-93.

Mosadeghrad, A.M. (2014). Why TQM programmes fail? A pathology approach. The TQM Journal, 26, 160-187. doi:10.1108/TQM-12-2010-0041

Oakland, J. (2011). Leadership and policy deployment: the backbone of TQM. Total Quality Management and Business Excellence, 22, 517-534.

Park, H. (2012). Factors affecting quality and performance - a case study of Korean aircraft maintenance unit. Total Quality Management and Business Excellence, 23, 197-219. doi:10.1080/14783363.2011.639560

Powell, T.C. (1995). Total quality management as competitive advantage: A review and empirical study. Strategic Management Journal, 16(1), 15-37. doi:10.1002/smj.4250160105

Saraph, J.V., Benson, P., \& Schroeder, R.G. (1989). An Instrument for Measuring the Critical Factors of Quality Management. Decision Sciences, 20(4), 810-829. doi:10.1111/j.1540-5915.1989.tb01421.x

Tsaur, S.H., \& Lin, Y.C. (2004). Promoting service quality in tourist hotels: The role of HRM practices and service behaviou.Tourism Management, 25(4), 471-481. doi:10.1016/S0261-5177(03)00117-1

Vora, M.K. (2013). Business excellence through sustainable change management. The TQM Journal, 25, 625-640. doi:10.1108/TQM-07-2013-0080

Wang, C.-. (2012). Total quality management, market orientation and hotel performance: the moderating effects of external environmental factors. International Journal of Hospitality Management, 31, 119-129. 
Milovanović V.: Total Quality Management as a Profitability Factor in the Hotel...

-World Economic Forum. . Global Competitiveness Report 2012-2013. Retrieved from http://reports.weforum.org/global-competitiveness-report-2012-2013/

Yeh, Y. (2003). Implementing a sustainable TQM system: employee focus. TQM Magazine, 15(4), 257-265. doi:10.1108/09544780310486164 